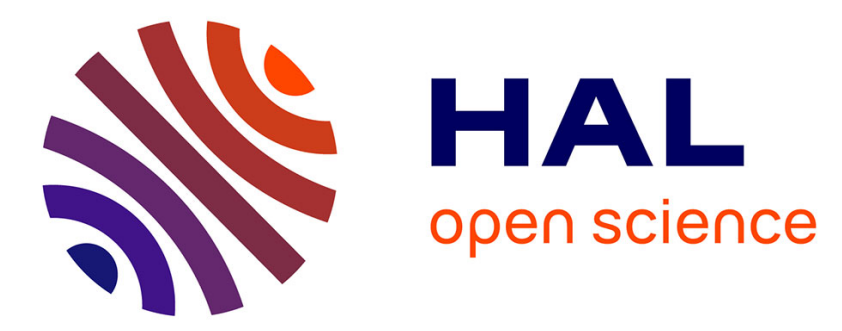

\title{
Dynamic and supramolecular organisation of $\alpha$-lactalbumin/lysozyme microspheres: A microscopic study
}

Michaël Nigen, Cédric Gaillard, Thomas Croguennec, Marie-Noëlle Madec, Said Bouhallab

\section{To cite this version:}

Michaël Nigen, Cédric Gaillard, Thomas Croguennec, Marie-Noëlle Madec, Said Bouhallab. Dynamic and supramolecular organisation of $\alpha$-lactalbumin/lysozyme microspheres: A microscopic study. Biophysical Chemistry, 2009, 146 (1), pp.30. 10.1016/j.bpc.2009.10.001 . hal-00594411

HAL Id: hal-00594411

https://hal.science/hal-00594411

Submitted on 20 May 2011

HAL is a multi-disciplinary open access archive for the deposit and dissemination of scientific research documents, whether they are published or not. The documents may come from teaching and research institutions in France or abroad, or from public or private research centers.
L'archive ouverte pluridisciplinaire HAL, est destinée au dépôt et à la diffusion de documents scientifiques de niveau recherche, publiés ou non, émanant des établissements d'enseignement et de recherche français ou étrangers, des laboratoires publics ou privés. 


\section{Accepted Manuscript}

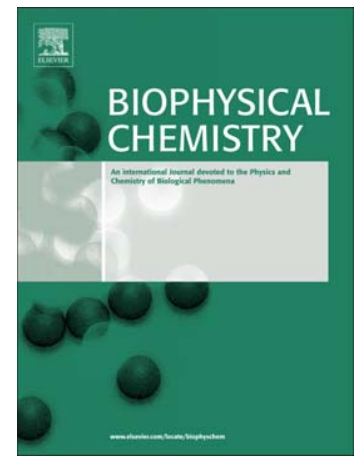

Dynamic and supramolecular organisation of $\alpha$-lactalbumin/lysozyme microspheres: A microscopic study

Michaël Nigen, Cédric Gaillard, Thomas Croguennec, Marie-Noëlle Madec, Saïd Bouhallab

PII:

S0301-4622(09)00202-6

DOI:

doi: 10.1016/j.bpc.2009.10.001

Reference:

BIOCHE 5304

To appear in: Biophysical Chemistry

Received date: 25 August 2009

Revised date: $\quad 2$ October 2009

Accepted date: 4 October 2009

Please cite this article as: Michaël Nigen, Cédric Gaillard, Thomas Croguennec, Marie-Noëlle Madec, Saïd Bouhallab, Dynamic and supramolecular organisation of $\alpha$ lactalbumin/lysozyme microspheres: A microscopic study, Biophysical Chemistry (2009), doi: $10.1016 /$ j.bpc.2009.10.001

This is a PDF file of an unedited manuscript that has been accepted for publication. As a service to our customers we are providing this early version of the manuscript. The manuscript will undergo copyediting, typesetting, and review of the resulting proof before it is published in its final form. Please note that during the production process errors may be discovered which could affect the content, and all legal disclaimers that apply to the journal pertain. 


\title{
Dynamic and supramolecular organisation of $\alpha$-lactalbumin/lysozyme microspheres: a microscopic study
}

\author{
Michaël Nigen ${ }^{\mathrm{a}}$, Cédric Gaillard ${ }^{\mathrm{b}}$, Thomas Croguennec ${ }^{\mathrm{a}}$, \\ Marie-Noëlle Madec ${ }^{\mathrm{a}}$, Saïd Bouhallab ${ }^{\mathrm{a}^{*}}$
}

a: INRA, Agrocampus Ouest, UMR1253, Science \& Technologie du Lait et de l'Euf, 65 rue de Saint Brieuc, F-35000 Rennes, France.

${ }^{\mathrm{b}}$ : INRA, UR1268 Biopolymères Interactions Assemblages, Rue de la Geraudiere, F-44316 Nantes Cedex 3, France.

Running title: Formation and dynamic of $\alpha$-Lactalbumin and Lysozyme assembly

Keywords: $\alpha$-lactalbumin; lysozyme; assembly mechanism; microspheres; CSLM; AFM; TEM

\footnotetext{
* Corresponding author : E-mail address : said.bouhallab@rennes.inra.fr
} 


\section{Abbreviations}

AFM: atomic force microscopy; apo $\alpha$-LA: calcium depleted $\alpha$-lactalbumin; CSLM: confocal scanning laser microscopy; FITC: fluorescein isothiocyanate; LYS: hen egg white lysozyme;

RBITC: rhodamine B isothiocyanate; SEM: scanning electron microscopy; TEM: Transmission electron microscopy 


\section{ABSTRACT}

Apo $\alpha$-lactalbumin (apo $\alpha$-LA) and lysozyme (LYS), two homologous globular proteins have been shown to be able to interact and self-assemble to form microspheres. We report on the organisation and the mechanism of such protein assembly process using a variety of microscopic techniques. We demonstrated that proteins involved into apo $\alpha$-LA/LYS microspheres exchange with those free in solution. The exchange process takes place from the periphery to the centre of the microspheres. The formed spherical particles observed after fixed incubation time were found to be either individual or aggregated according to the total protein concentration leading to structures with different size and morphology. It appears that protein assembly occurs throughout successive steps of aggregated spherical particles that reorganise into biggest isolated microspheres. Direct microscopic observations over time confirm that microspheres resulted from a reorganisation of aggregated, clustered nanospheres. We propose that the formation of apo $\alpha$-LA/LYS microspheres follows an “aggregation-reorganisation” mechanism. 


\section{Introduction}

Protein assembly into various supramolecular structures (aggregates, fibres, nanotubes, spherulites, etc) is a widespread phenomenon in biological science [1-4]. Nowadays, it is well documented that the amphiphilic property of proteins is a driving force to self-assemble into a large family of supramolecular structures of high interest for making new soft materials. The formation of such supramolecular structures is strongly dependent on physico-chemical conditions and protein conformation.

The assembly between globular proteins usually requires the modification of protein conformation or/and the formation of specific oligomers [5]. Nowadays, understanding protein assembly mechanisms constitutes a great challenge for good and adequate control of the nature and properties of formed supramolecular structures. For instance, most studies in this field are focused on monoprotein systems, particularly aiming to elucidate the fibrillation mechanism of proteins or peptides [6-8]. Understanding protein assembly mechanisms in more complex systems, involving more than one protein appears also of fundamental interest for the elaboration of new protein assemblies with specific functionalities [9-12].

In our previous studies, we evidenced the molecular interaction and the assembly between two oppositely charged globular proteins, hen egg white lysozyme (LYS) and bovine calcium-depleted $\alpha$-lactalbumin (apo $\alpha$-LA) that led to microspheres at $45^{\circ} \mathrm{C}$ [13]. LYS and apo $\alpha$-LA are two proteins constituted of 129 and 123 amino acids, respectively, that present homologous three dimensional structures, including four disulfide bonds [14-17]. The apo form of $\alpha$-LA is a crucial conformation because no assembly was detected when the native, calcium loaded $\alpha$-LA was mixed with LYS. We showed that at molecular level, LYS and apo $\alpha$-LA interact via electrostatic forces to form oligomers assumed to be heterodimers [18]. These heterodimers were assumed to be the starting blocks for further self-assembly and 
growth into supramolecular structures. At $45^{\circ} \mathrm{C}$, such self-assembly led to the formation of spherical particles containing both proteins in equimolar ratio and perfectly co-localised in the overall supramolecular structures [19].

Due to the advance of microscopy, its versatility and high resolution, it has become possible to investigate in detail the various structures that biomolecules can form during selfassembly as well as the kinetic and dynamic of such biological process. In the present work, we further investigated the organisation and the internal dynamic of apo $\alpha$-LA/LYS microspheres once formed at $45^{\circ} \mathrm{C}$ and also characterised the mechanism of assembly between these two proteins at mesoscopic level using microscopic techniques. Based on our results obtained at different level of observation, from molecular to microscopic level, a putative mechanism of apo $\alpha$-LA/LYS assembly to form microspheres is proposed.

\section{Materials and methods}

\subsection{Materials}

Commercial lysozyme (LYS) was purchased from Ovonor and contained $95 \%$ of LYS and $3 \%$ of chloride ions. Holo $\alpha$-lactalbumin (holo $\alpha$-LA) was purified from bovine whey as reported by Caussin et al. [20]. Apo $\alpha$-lactalbumin (apo $\alpha$-LA) was prepared by dialysis of a solution of holo $\alpha$-LA against deionised water at $\mathrm{pH} 3$ during $48 \mathrm{~h}$ at $4{ }^{\circ} \mathrm{C}$ using a $6-8000 \mathrm{Da}$ nominal cut off membrane (Spectrum Laboratories, US \& Canada) in order to remove calcium ions. Then, $\mathrm{pH}$ of the apo $\alpha$-LA solution was adjusted to $\mathrm{pH} 7$ with $1 \mathrm{M} \mathrm{NaOH}$ and freeze-dried; the apo $\alpha$-LA powder containing less than $2 \%$ of calcium (mole/mole). Fluorescein isothiocyanate (FITC) and rhodamine B isothiocyanate (RBITC) were purchased 
from Sigma-Aldrich (L'Isle d'Abeau Chesnes, France). The other reagents were of analytical grade.

\subsection{Confocal scanning laser microscopy (CSLM)}

A Nikon C1Si Laser Scanning Confocal Imaging System on inverted microscope TE2000-E (Nikon, Champigny-sur-Marne, France), equipped with an argon ion laser and a helium/neon laser emitting respectively at 488 and $543 \mathrm{~nm}$, was used to investigate the organization and the dynamic of apo $\alpha$-LA/LYS microspheres. CSLM images were acquired with a $\times 100$ objective (oil immersion, numeric aperture 1.40 ) using the standard mode. FITC and RBITC were excited respectively at 488 and $543 \mathrm{~nm}$, while the emitted light from FITC and RBITC were recovered at 515/30 and 590/50 nm, respectively. The software used for CSLM images was EZ-C1 version 3.40 (Nikon).

\subsection{Scanning Electron Microscopy (SEM)}

Mixtures of apo $\alpha$-LA and LYS prepared at $45^{\circ} \mathrm{C}$ were deposited on an ester cellulose membrane. Samples were fixed in $30 \mathrm{mM}$ Tris/ $\mathrm{HCl}$ buffer $(\mathrm{pH} 7.5)$ containing $15 \mathrm{mM} \mathrm{NaCl}$ and $2.5 \%(\mathrm{v} / \mathrm{v})$ glutaraldehyde for $1 \mathrm{~h}$ at room temperature. Then, samples were dehydrated using successive ethanol solutions at $50 \%, 75 \%, 85 \%, 95 \%$ and $100 \%$ (elapsed time per solution was $5 \mathrm{~min})$. Following dehydration, the samples were critical point dried using carbon dioxide and gold-coated. The experiments were carried out using a JEOL JSM 6301F field emission scanning electron microscope (SEM) with accelerating voltage of $9 \mathrm{kV}$ (JEOL, Tokyo, Japan). 


\subsection{Transmission Electron Microscopy (TEM)}

A drop of each aqueous mixture of apo $\alpha$-LA and LYS prepared at $45^{\circ} \mathrm{C}$ was first placed on a carbon-coated TEM copper grid (Quantifoil, Germany). The excess of solution was removed using Whatman paper and the grid let to air-drying. The samples were then negatively stained with uranyl acetate (Merck, Germany). For that, the sample-coated TEM grid was successively placed on a drop of an aqueous solution of uranyl acetate $(2 \% \mathrm{w} / \mathrm{w})$ and on a drop of distilled water. The grid was then air-dried before introducing it in the electron microscope. Negative staining was not applied on more concentrated protein sample i.e. $0.2 \mathrm{mM}$.

The samples were viewed using a JEM-1230 TEM (JEOL, Japan) operating at $80 \mathrm{kV}$ and equipped with a $\mathrm{LaB}_{6}$ filament. The Images were acquired using a ES500W CCD camera with a resolution of $1.35 \mathrm{~K} \times 1.04 \mathrm{~K}$.

\subsection{Atomic Force Microscopy (AFM)}

Atomic force microscope (AFM) images were acquired in air using an Autoprobe CP Park Scientific Instrument (Sunnyvale, CA). AFM images were recorded in the Tapping mode using conventional pyramidal silicon nitride cantilevers obtained from Digital Instruments (Santa Barbara, CA). All the Tapping mode images (both amplitude and topography images) were acquired at the lowest possible stable scanning force, less than $10 \mathrm{nN}$.

Mica substrates were prepared by cleaving to produce a smooth surface prior to sample deposition. For each apo $\alpha$-LA/LYS mixture, pre-incubated at $45^{\circ} \mathrm{C}$, aliquots of $5 \mu \mathrm{L}$ were spread onto freshly cleaved mica sheets and dried under argon flux for about 15 min. 


\subsection{Protein Labelling}

LYS and apo $\alpha$-LA were labelled separately using covalently linking fluorescent dyes: FITC and RBITC. The labelling was achieved as follows: aqueous solutions of $0.2 \mathrm{mM}$ of protein (LYS or apo $\alpha$-LA) were adjusted to $\mathrm{pH} 8.5$ using $1 \mathrm{M} \mathrm{NaOH}$ and filtered through 0.2 $\mu \mathrm{m}$ membrane. Subsequently, $100 \mu \mathrm{L}$ of the dye solution, dissolved in dimethylsulfoxide at a concentration of $1 \mathrm{mg} \cdot \mathrm{mL}^{-1}$ (2 to $2.5 \mathrm{mM}$ ), were added to the protein solutions. The crosslinking reaction occurred at room temperature under gentle stirring during $3 \mathrm{~h}$. Then, the solutions were firstly extensively dialysed against $10 \mathrm{mM}$ Tris/ $\mathrm{HCl}$ buffer $(\mathrm{pH} 7)$ containing $0.6 \mathrm{M} \mathrm{NaCl}$ to remove free dyes and secondly against deionised water at $\mathrm{pH} 7$ to remove salts using dialysis membrane (Spectrum Laboratories, US \& Canada) with a nominal cut off of 6$8000 \mathrm{Da}$. The solutions were then centrifuged at $12000 \mathrm{~g}$ and the supernatants were recovered and freeze-dried. Under these labelling conditions, about $5 \%$ of apo $\alpha$-LA or LYS had linked one mole of the probe per mole of protein as assessed by mass spectrometry analysis (results not shown)

\subsection{Préparation of apo $\alpha$-LA/LYS assembly}

Stock solutions of LYS and apo $\alpha$-LA (labelled or unlabelled) were prepared by solubilisation of protein powders in $30 \mathrm{mM}$ Tris/ $\mathrm{HCl}$ buffer ( $\mathrm{pH} 7.5$ ) containing $15 \mathrm{mM} \mathrm{NaCl}$ and filtered through $0.2 \mu \mathrm{m}$ membrane. Protein concentration was determined by measuring the absorbance at $280 \mathrm{~nm}$ using extinction coefficients of 2.01 and $2.64 \mathrm{~L}_{\mathrm{g}} \mathrm{g}^{-1} \mathrm{~cm}^{-1}$ for apo $\alpha-$ LA and LYS, respectively. For labelled proteins, the absorbance at $280 \mathrm{~nm}$ was corrected for the contribution of the fluorochrome as previously reported [21]. apo $\alpha$-LA/LYS assemblies were formed at $45^{\circ} \mathrm{C}$ by mixing equimolar quantities of LYS and apo $\alpha$-LA (labelled and 
unlabelled) stock solutions to obtain final protein concentrations ranging from 0.02 to 0.2 mM. Unlabelled proteins were used for TEM, AFM and SEM experiments while at least one labelled protein was used for CSLM studies. The formed assemblies were observed after equilibration of the mixtures during 30 minutes at $45^{\circ} \mathrm{C}$ except for kinetic study. In this last case, LYS-RBITC was mixed with unlabelled apo $\alpha$-LA and aliquots were taken at various time intervals for direct observation using CSLM.

\subsection{Internal dynamic of apo $\alpha$-LA/LYS microspheres}

Microspheres were first formed by mixing Fluorescent LYS and apo $\alpha$-LA at a total protein concentration of $0.2 \mathrm{mM}$ using LYS-FITC. In typical experiment, $50 \mu \mathrm{L}$ of $0.2 \mathrm{mM}$ apo $\alpha$-LA solution were mixed with $50 \mu \mathrm{L}$ of $0.2 \mathrm{mM} \mathrm{LYS}$-FITC. After 30 minutes at $45^{\circ} \mathrm{C}$, $50 \mu \mathrm{L}$ of $0.2 \mathrm{mM}$ LYS-RBITC solution were then added to start the exchange experiment. Protein exchange between microspheres and the solution as a function of time was monitored by CSLM throughout emitted light from FITC and RBITC included in apo $\alpha$-LA/LYS microspheres. We explored the advantage of CLSM to obtain information about the threedimensional distribution of fluorescent probes along special dimensions of a microparticles from the surface to the inside of the structure. The collected coplanar cross sections allowed the three-dimensional reconstruction of the inspected particles.

\subsection{Stability of apo $\alpha$-LA/LYS microspheres}

Apo $\alpha$-LA/LYS microspheres were prepared at a total protein concentration of $0.2 \mathrm{mM}$ as described above. After 30 minutes equilibration at $45^{\circ} \mathrm{C}$, aliquot of $\mathrm{CaCl}_{2}$ solution in 30 $\mathrm{mM}$ Tris/ $\mathrm{HCl}$ buffer ( $\mathrm{pH} 7.5$ ) containing $15 \mathrm{mM} \mathrm{NaCl}$ was then added to reach a final 
$\mathrm{Ca}^{2+} /$ apo $\alpha$-LA molar ratio of 1 . The mixture was further left for 15 minutes at $45^{\circ} \mathrm{C}$ before observation using TEM.

\section{Results and Discussion}

\subsection{Microscopic observations of apo $\alpha$-LA/LYS microspheres}

Complementary microscopic techniques were combined to further characterize the supramolecular spherical structures formed after mixing LYS and apo $\alpha$-LA. SEM, CSLM, TEM and AFM micrographs of such microspheres formed at protein concentration of $0.2 \mathrm{mM}$ are shown in Figure 1. The two proteins self-assemble to form spherical structures with low polydispersity i.e. diameter of 1.5 to $3 \mu \mathrm{m}$ at the used protein concentration. As we already showed in a previous work [19], LYS and apo $\alpha$-LA were homogeneously distributed and colocalised in apo $\alpha$-LA/LYS microspheres as illustrated by CSLM image of apo $\alpha$-LA-FITC and LYS-RBITC mixture (Figure 1B). Apo $\alpha$-LA/LYS microspheres observed by the different types of microscopy globally appeared as dense and spherical-shaped particles with sizes in well accordance from one image to another (Figure 1A to D). Few morphological differences appeared on the particles and were attributed to the sample specific preparation methods used for each technique. For instance, a slight deformation of the microspheres upon adsorption onto the mica substrate and tip effect account for the slightly less-spherical shape observed in the AFM micrograph (Figure 1D). Topography analysis performed on several particles showed that microspheres had an average height of $2.7 \mu \mathrm{m}$.

\subsection{Dynamic of apo $\alpha$-LA/LYS microspheres}


The next characterisation step was to gain more insight on the dynamic of proteins once incorporated into microspheres. For such purpose, our approach was to monitor protein exchange between spheres and solution using CSLM and one of the two proteins (i.e.. LYS) labelled with FITC and RBITC. Green microspheres were first formed by pre-incubation of unlabelled apo $\alpha$-LA with LYS-FITC at $45^{\circ} \mathrm{C}$ during 30 minutes of equilibration (Figure 2A); then LYS-RBITC was added to the sample to start, if any, the exchange process. This process (called green to orange) was monitored by CSLM observations over time. Figure 2B shows that an orange ring appeared at the periphery of a microsphere observed 5 minutes after the addition of LYS-RBITC. It must be noticed that the rate of colour change varied from one microsphere to another (heterogeneous initial kinetic exchange) and consequently micrographs are chosen to better illustrate the kinetic process. The orange ring, originated from the combination of FITC and RBITC fluorescence signals, evidenced the inclusion of LYS-RBITC (red) into previously formed LYS-FITC/apo $\alpha$-LA microspheres (green). The observed orange ring grew up progressively over time to cover half of a microsphere after 15 min. A completely orange apo $\alpha$-LA/LYS microsphere was detected 75 minutes after the addition of LYS-RBITC (Figure 2D), indicating that the added free labelled proteins were able to reach the centre of the microsphere. The same kinetics were observed during inverse experiment starting with RBITC labelled LYS (red to orange) (not shown). These results highlight that protein molecules included into microspheres are in continuous equilibrium with those in soluble phase. Accordingly, at the used total protein concentration, the exchange kinetic took about 1 hour progressing from the exterior to the interior of a given microsphere. Hence, we report here unprecedented observation that protein molecules included into microspheres are not settled but they can slowly diffuse into these particles and exchange with the medium. We must note however that the spatial resolution of CSLM did not allow ascertaining the exact nature of molecular species that exchange with the microspheres. These 
species could be either monomers of LYS-RBITC, heterodimers and/or larger nanostructures with incorporated LYS-RBITC.

Biesheuvel et al. have developed a theoretical approach to discuss the behaviour of oppositely charged proteins in mixed solution and the repartition equilibrium of proteins between soluble and complex phases $[22,23]$. This approach is based on chemical potentials of proteins and considering the analogy with the solubility limit of poorly soluble salts. The results reported here constitute the first experimental evidence of the reversibility and dynamic of such equilibrium between protein molecules in solution and those included in the macromolecular structures (complex phase). Also, our earlier observations on the fact that free protein molecules in solution co-existed with apo $\alpha$-LA/LYS microspheres at all protein concentrations tested further support the occurrence of such equilibrium [13].

The destabilisation behaviour of microspheres under high ionic strength or in the presence of divalent cations, in particular calcium, shown by turbidity measurements [24], is also in favour of a dynamic character of these supramolecular structures. The destabilisation of apo $\alpha$-LA/LYS microspheres by calcium ions was further investigated here using TEM. Addition of calcium on pre-formed apo $\alpha$-LA/LYS microspheres reduced the number of observed particles on TEM micrographs (data not shown). Furthermore, the morphology of microspheres was clearly altered by calcium (Figure 3A): the periphery of the microspheres appeared more diffuse, less dense and heterogeneous (Figure 3), while their "core" seemed always dense and homogeneous, similar to microspheres observed without calcium (Figure 1C). The focus on one microsphere showed that calcium induced the appearance of a clear crown with release of small dense particles from the periphery (Figure 3B). Consequently, the calcium-induced destabilisation process of apo $\alpha$-LA/LYS microspheres occurred as an erosion phenomenon. These results are in well accordance and clearly explain the already observed decrease of both (i) microspheres size and (ii) proteins quantity included into 
microspheres after the addition of calcium [24]. Furthermore, comparison of CSLM results (Figure 2B, C) and sensitivity to calcium (Figure 3B) indicate formation of a crown at the periphery of the particles. These observations support the idea that apo $\alpha$-LA/LYS microspheres are build-up from the association of smaller primary complexes, i.e. nanospheres, as already suggested from our previous physico-chemical study [24]. Hence, the cohesive forces between constitutive nanoparticles and/or their accessibility clearly differ from the exterior to the heart of the microspheres.

\subsection{Putative mechanism of apo $\alpha$-LA/LYS microspheres formation : kinetic evidence and dependence of apo $\alpha$-LA/LYS assemblies on protein concentration}

TEM technique was used to follow what is happening during apo $\alpha$-LA/LYS assembly at different total protein concentration but at constant apo $\alpha$-LA/LYS molar ratio of 1 . The two proteins were mixed at total protein concentration ranging from 0.02 to $0.2 \mathrm{mM}$ and then incubated at $45^{\circ} \mathrm{C}$ before microscopic observations. The assembly between LYS and apo $\alpha$ LA at protein concentration of $0.02 \mathrm{mM}$ led to the formation of heterogeneous clusters of few hundred nanometers that were constituted by nanospheres with diameters of about $10 \mathrm{~nm}$ (Figure 4A). At this protein concentration, a significant number of small isolated nanospheres were also detected. Well isolated nanospheres with diameters of about $20 \mathrm{~nm}$ were observed when the protein concentration was increased from 0.02 to $0.04 \mathrm{mM}$ (Figure 4B). Clusters or particles larger than $20 \mathrm{~nm}$ were not observed at this protein concentration. At protein concentration of $0.1 \mathrm{mM}$, LYS and apo $\alpha$-LA self-assembled to form heterogeneous clustered nanospheres with size ranging between 400-700 nm (Figure 4C). These clusters are constituted of spherical particles the size of which increased with increasing total protein concentration. The mixtures of LYS and apo $\alpha$-LA at protein concentration of $0.2 \mathrm{mM}$ 
induced the formation of well isolated spherical microspheres with diameters of 2-3 $\mu \mathrm{m}$, as widely described in the previous section (Figure 4D).

This microscopic study, performed at fixed time for all concentrations tested, shows that LYS and apo $\alpha$-LA self-assembled into spherical particles at $45^{\circ} \mathrm{C}$ that can be either clusters of nanospheres or isolated nano- or microspheres depending on protein concentration. The total protein concentration affected also the final size of observed spheres. Such concentration dependence of particle size has already been described in other polymer systems [25-27]. As an example, the size of spheres formed by spider silk protein was shown to depend on protein concentration and equilibrium of solubility $[25,26]$. Solute concentration was also found to be among the key physico-chemical factors that determine a finite size of particles formed between lysosyme and charged polyelectrolyte [27]. Apo $\alpha$-LA/LYS assembly seems to occur as successive steps between clustered and isolated spherical particles, which are under control of protein concentration. Interestingly, the diameter of spherical particles forming the aggregates seemed to be very close to that of isolated spherical particles formed at lowest protein concentration. So, the aggregation of isolated spherical particles can constitute a prerequisite for their growth and the formation of larger isolated spherical particles.

More direct evidence of the occurrence of such self-organisation process from aggregated to isolated spheres was accomplished by confocal microscopy observations over time at fixed protein concentration. The results shown in Figure 5 clearly indicate timeevolution of the morphology of formed supramolecular structures. The first observation took place $0.5 \mathrm{~min}$ after protein mixing and at this stage individual spherical structures were not observed. Only clusters of nanoparticles were detected (figure 5a). These clustered structures progressively re-organise to form well-defined microspheres (Figure 5f) after 6 min incubation at the used total protein concentration. The observed self-organisation process is probably driven by the general trend toward a favourable minimal interface area of the 
particle. As far as a critical size of clustered nanosparticles is reached, reorganisation in more thermodynamically stable structure occurs. The thermodynamic parameters that trigger aggregated spheres reorganisation of clusters into larger isolated spherical structures is not understood. Several models, including nucleation-growth model have been reported to describe polymers and biopolymers self-assemblies in solution. Bohr et al. [28] described two possible growth processes during the spherical aggregation observed for lysozyme or ribonuclease as a function of protein concentration. In the first one, the protein aggregates out from nucleation point in a spherical symmetric way resulting in massive beads. In the other one, protein sheets assemble with a thermodynamically equilibrated curvature resulting in a hollow shell with further shells inside. Whatever the process, the outer appearance of final spheres were the same. The assembly process of LYS/ apo $\alpha$-LA seems to follow the hollow shells process with the re-organisation of clusters into energetically favourable spherical particles. Interestingly, similar re-organisation pathway was shown recently to prevail during polysaccharide induced formation of amorphous calcium carbonate films [29].

As a conclusion, we propose that the formation of apo $\alpha$-LA/LYS microspheres follows a successive "aggregation-reorganisation" mechanism as illustrated in Figure 6. LYS and apo $\alpha$-LA interact first via electrostatic forces to form heterodimers at molecular level [18]. The formed apo $\alpha$-LA/LYS heterodimers appear to be the basic blocks for self-assembly that evolve first toward clusters of small nanospheres. Aggregation of these nanospheres is assumed to be favoured by the experimentally global neutral net charge obtained for these particles (results not shown). Finally, if the total protein concentration and/or incubation time are favourable, a reorganisation of these clusters into well isolated spherical particles occurs. The proteins involved in the final spherical particles are shown to be in continuous exchange with those in free phase, underlying the dynamic property of these supramolecular structures. However, the formation process and the observed dynamic that involves protein dissociation 
could follow two distinct and independent pathways. Taken together these results, it is also possible that the growth and self-organisation process the two proteins follow the well-known Ostwald ripening process as suggested recently for similar formation process observed for calcium carbonate films [29]. Ostwald process involves that larger particles grow at the expense of smaller ones. Investigations are in progress to confirm the proposed putative mechanism of assembly between these two globular proteins. In particular combination of microscopy and rapid kinetic studies - microfluidic devices, time-lapse microscopy - will be helpful and promising ways to further elucidate the mystery behind assembly processes in protein binary systems.

\section{Acknowledgments}

The authors would like to thank J. Le Lannic (C.M.E.B.A., Rennes) for his contribution in the acquisition of scanning electron microscopy images and J. Jardin (UMR1253 INRA, Rennes) for performing mass spectrometry analyses of labelled proteins. Part of this work was supported by the French National Research Agency, (Agence Nationale de la Recherche, Grant ANR-07-PNRA-010, project LACLYS). 


\section{References}

[1] J. Goers, S.E. Permyakov, E.A. Permyakov, V.N. Uversky and A.L. Fink, Conformational prerequisites for $\alpha$-lactalbumin fibrillation, Biochemistry 41 (2002) 12546-12551.

[2] J.F. Graveland-Bikker and C.G. de Kruif, Unique milk protein based nanotubes: Food and nanotechnology meet, Trends in Food Sci. Technol 17 (2006) 196-203.

[3] R. Ipsen, J. Otte and K.B. Qvist, Molecular self-assembly of partially hydrolysed $\alpha-$ lactalbumin resulting in strong gels with a novel microstructure, J. Dairy Res. 68 (2001) $277-286$.

[4] M.R.H. Krebs, G.L. Devlin and A.M. Donald, Protein particulates: Another generic form of protein aggregation? Biophys. J. 92 (2007) 1336-1342.

[5] F. Chiti F and C.M. Dobson, Protein misfolding, functional amyloid, and human disease, Annu. Rev. Biochem. 75 (2006) 333-366.

[6] M.R.H. Krebs, E.H.C. Bromley, S.S. Rogers and A.M. Donald, The mechanism of amyloid spherulite formation by bovine insulin, Biophys. J. 88 (2005) 2013-2021.

[7] A. Lomakin, D.S. Chung, G.B. Benedek, D.A. Kirschner and D.B. Teplow, On the nucleation and growth of amyloid $\beta$-protein fibrils: Detection of nuclei and quantitation of rate constants, Proc. Nat. Acad. Sci. 93 (1996) 1125-1129.

[8] J. Leonil, G. Henry, D. Jouanneau, M.M. Delage, V. Forge and J.L. Putaux, Kinetics of fibril formation of bovine $\kappa$-casein indicate a conformational rearrangement as a critical step in the process, J. Mol. Biol. 381(2008) 1267-1280.

[9] P. Sanguansri and M.A. Augustin, Nanoscale materials development - a food industry perspective, Trends Food Sci. Technol. 17 (2006) 547-556. 
[10] S. Zhang, D.M. Marini, W. Hwang and S. Santoso, Design of nanostructured biological materials through self-assembly of peptides and proteins. Curr. Opin. Chem. Biol. 6 (2002) 865-871.

[11] S. Zhang, Fabrication of novel biomaterials through molecular self-assembly, Nat. Biotechnol. 21 (2003) 1171-1178.

[12] C. Viney, Self-assembly as a route to fibrous materials: concepts, opportunities and challenges, Curr. Opin. Solid State Mat. Sci. 8 (2004) 95-101.

[13] M. Nigen, T. Croguennec, D. Renard and S. Bouhallab, Temperature affects the supramolecular structures resulting from $\alpha$-lactalbumin-lysozyme interaction, Biochemistry 46, (2007) 1248-1255.

[14] H.A. McKenzie and F.H.J. White, Lysozyme and $\alpha$-lactalbumin: structure, function, and interrelationships, Adv. Prot. Chem. 41 (1991) 173-315.

[15] P.K. Qasba and S. Kumar S, Molecular divergence of lysozymes and $\alpha$-lactalbumin, Crit. Rev. Biochem. Mol. Biol. 32 (1997) 255-306.

[16] L.H. Greene, J.A. Grobler, V.A. Malinovskii, J. Tian, K.R. Acharya and K. Brew, Stability, activity and flexibility in $\alpha$-lactalbumin, Protein Eng. 12 (1999) 581-587.

[17] L.K. Iyer and P.K. Qasba, Molecular dynamics simulation of $\alpha$-lactalbumin and calcium binding c-type lysozyme, Protein Eng. 12, (1999) 129-139.

[18] M. Nigen, V. Le Tilly, T. Croguennec, D. Drouin-Kucma and S. Bouhallab, Molecular interaction between apo or holo $\alpha$-lactalbumin and lysozyme: Formation of heterodimers as assessed by fluorescence measurements, Biochim. Biophy. Acta. 1794 (2009) 709-715.

[19] M. Nigen, T. Croguennec, M.N. Madec and S. Bouhallab, Apo $\alpha$-lactalbumin and lysozyme are co-localized in their subsequently formed spherical supramolecular assembly, FEBS J. 274 (2007) 6085-6093. 
[20] F. Caussin, M.H. Famelart, J.L. Maubois and S. Bouhallab, Mineral modulation of thermal aggregation and gelation of whey proteins: From $\beta$-lactoglobulin model system to whey protein isolate, Lait 83 (2003) 353-364.

[21] S.Y. Mao, in: The protein Protocols Hanbook, ed. J.M. Walker, Conjuguaison of fluorochromes to antibodies (Humana Press, Totowa, New Jersey, 2002) pp 351-354.

[22] P.M. Biesheuvel, S. Lindhoud, R. de Vries and M.A. Cohen Stuart, Phase behavior of mixtures of oppositely charged nanoparticles: Heterogeneous Poisson-Boltzmann cell model applied to lysozyme and succinylated lysozyme, Langmuir 22 (2006) 1291-1300.

[23] P.M. Biesheuvel, S. Lindhoud, M.A. Cohen Stuart and R. de Vries, Phase behavior of mixtures of oppositely charged protein nanoparticles at asymmetric charge ratios. Phys. Rev. E 73 (2006) 041408.

[24] M. Nigen, T. Croguennec and S. Bouhallab, Formation and stability of $\alpha-$ lactalbumin-lysozyme spherical particles: Involvement of electrostatic forces, Food Hydrocoll. 23 (2009) 510-518.

[25] U.K. Slotta, S. Rammensee, S. Gorb and T. Scheibel, An Engineered Spider Silk Protein Forms Microspheres, Angew. Chem. Int. Ed. 47 (2008) 4592-4594.

[26] A. Lammel, M. Schwab, U. Slotta, G. Winter and T. Scheibel, Processing conditions for the formation of spider silk microspheres, ChemSusChem 1 (2008) 413-416

[27] J. Gummel, F. Boué, D. Clemens and F. Cousin, Finite size and inner structure controlled by electrostatic screening in globular complexes of proteins and polyelectrolytes, Soft Matter 4 (2008) 1653 - 1664.

[28] H. Bohr, A. Kühle, A.H. Sorensen and J. Bohr, Hierarchical organization in aggregates of protein molecules, Z. Phys. D 40 (1997) 513-515. 
[29] C. Zhong and C.C. Chu, Acid polysaccharide-induced amorphous calcium carbonate (ACC) films: colloidal nanoparticle self-organization process, Langmuir 25 (2009) 3045-3049. 


\section{Figure legends}

Figure 1
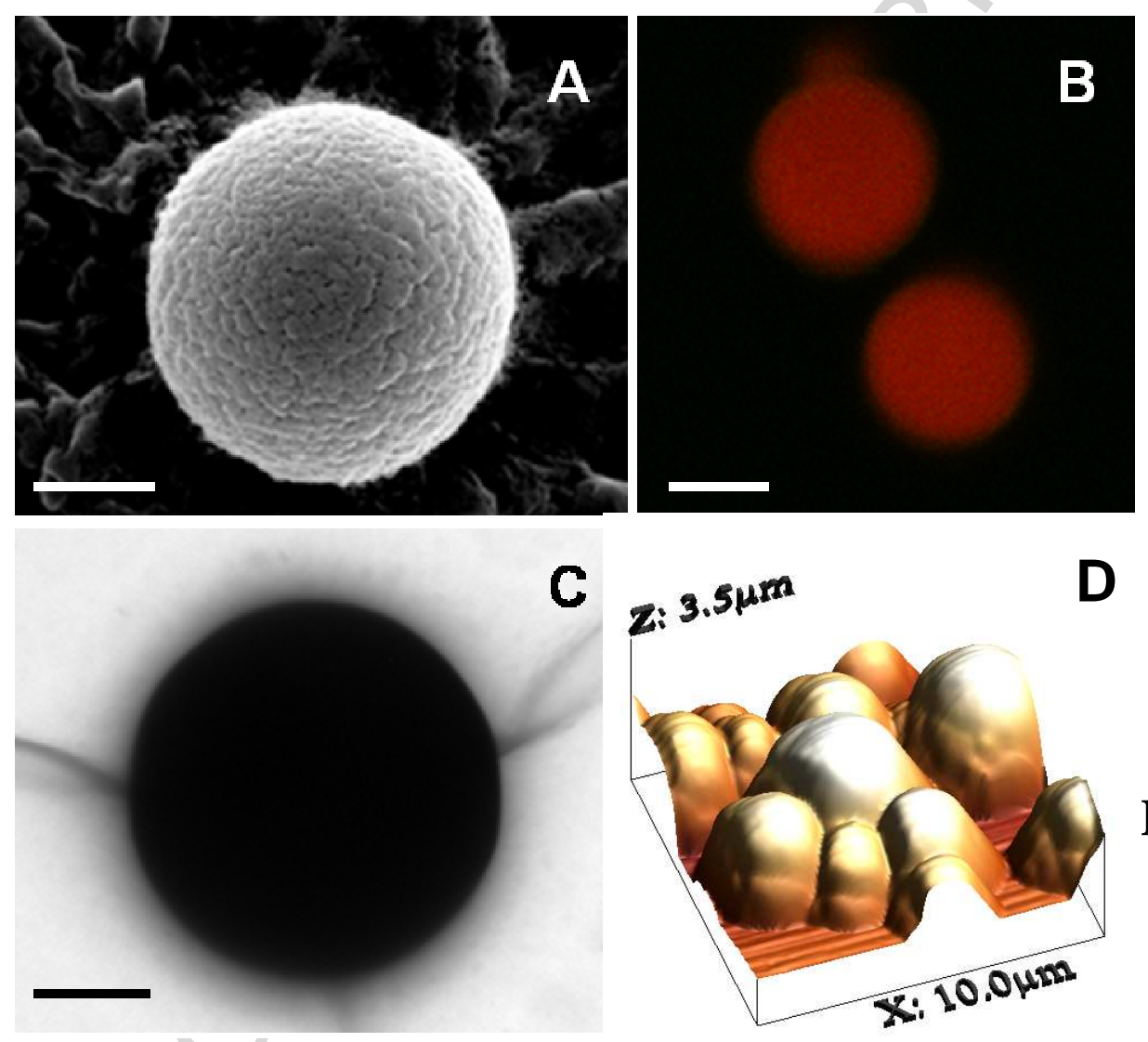

C

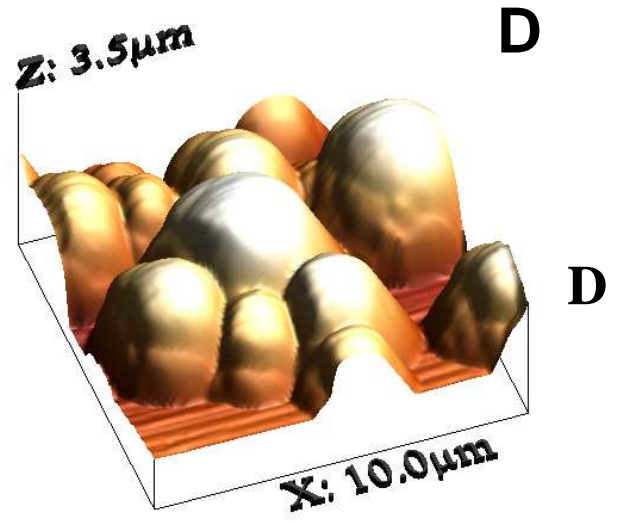

Figure 1. Visualization of apo $\alpha$-LA/LYS microspheres using (A) scanning electron microscopy, scale bar $=1 \mu \mathrm{m}$; (B) confocal scanning laser microscopy, scale bar $=2 \mu \mathrm{m}$; (C) transmission electron microscopy, scale bar $=0.5 \mu \mathrm{m}$ and (D) atomic force microscopy, scale bar $=2 \mu \mathrm{m}$. Microspheres were formed at $45^{\circ} \mathrm{C}$ in $30 \mathrm{mM}$ Tris/ $\mathrm{HCl}, 15 \mathrm{mM} \mathrm{NaCl} \mathrm{pH} 7.5$ with total protein concentration of $0.2 \mathrm{mM}$.

Figure 2 


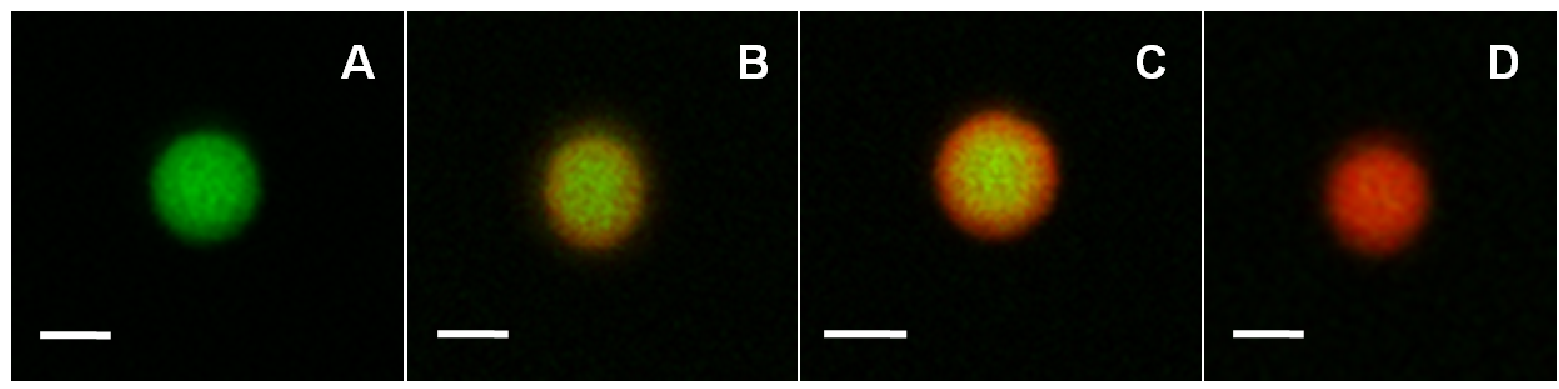

Figure 2. Internal dynamic of apo $\alpha$-LA/LYS microspheres and protein exchange between microspheres and solution. Apo $\alpha$-LA/LYS microspheres were pre-formed by mixing apo $\alpha$ LA and LYS-FITC at $45^{\circ} \mathrm{C}$. After 30 minutes, LYS-RBITC was added to the solution and the emitted light of FITC and RBITC included in apo $\alpha$-LA/LYS microspheres were recovered at various times: $0 \min (A), 5 \min (B), 15 \min (C)$ and $75 \min (D)$. Scale bars $=2 \mu \mathrm{m}$.

\section{Figure 3}

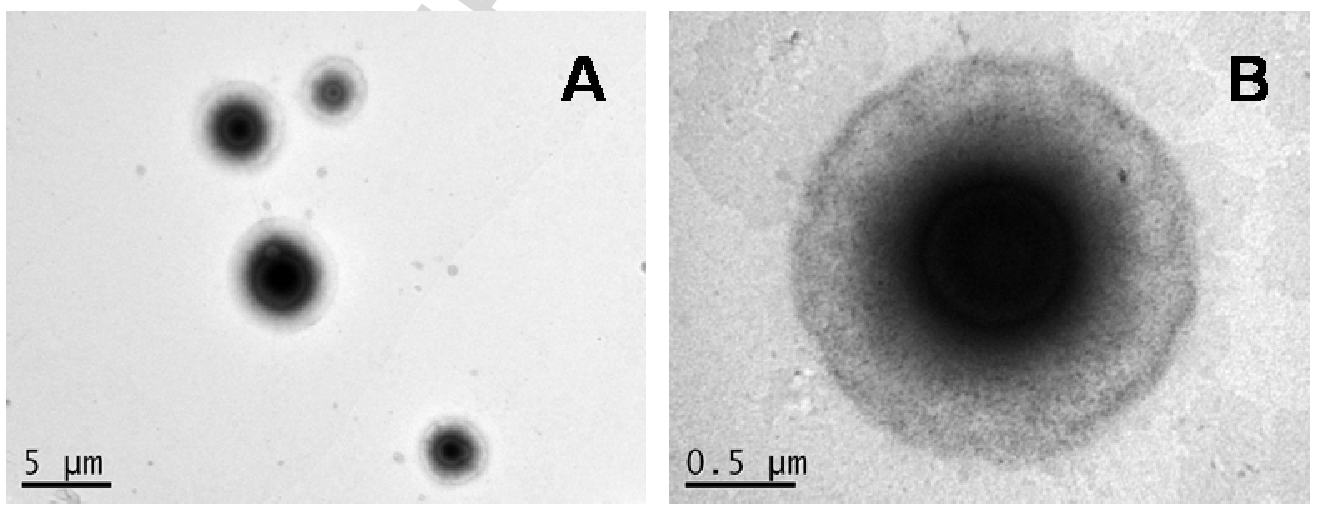

Figure 3. Transmission electron micrographs of apo $\alpha$-LA/LYS microspheres incubated in the presence of calcium ions for 15 minutes at $45^{\circ} \mathrm{C} . \mathrm{Ca}^{2+} /$ apo $\alpha$-LA molar ratio was 1. Scale bars represent $5 \mu \mathrm{m}(\mathrm{A})$ and $0.5 \mu \mathrm{m}(\mathrm{B})$.

\section{Figure 4}



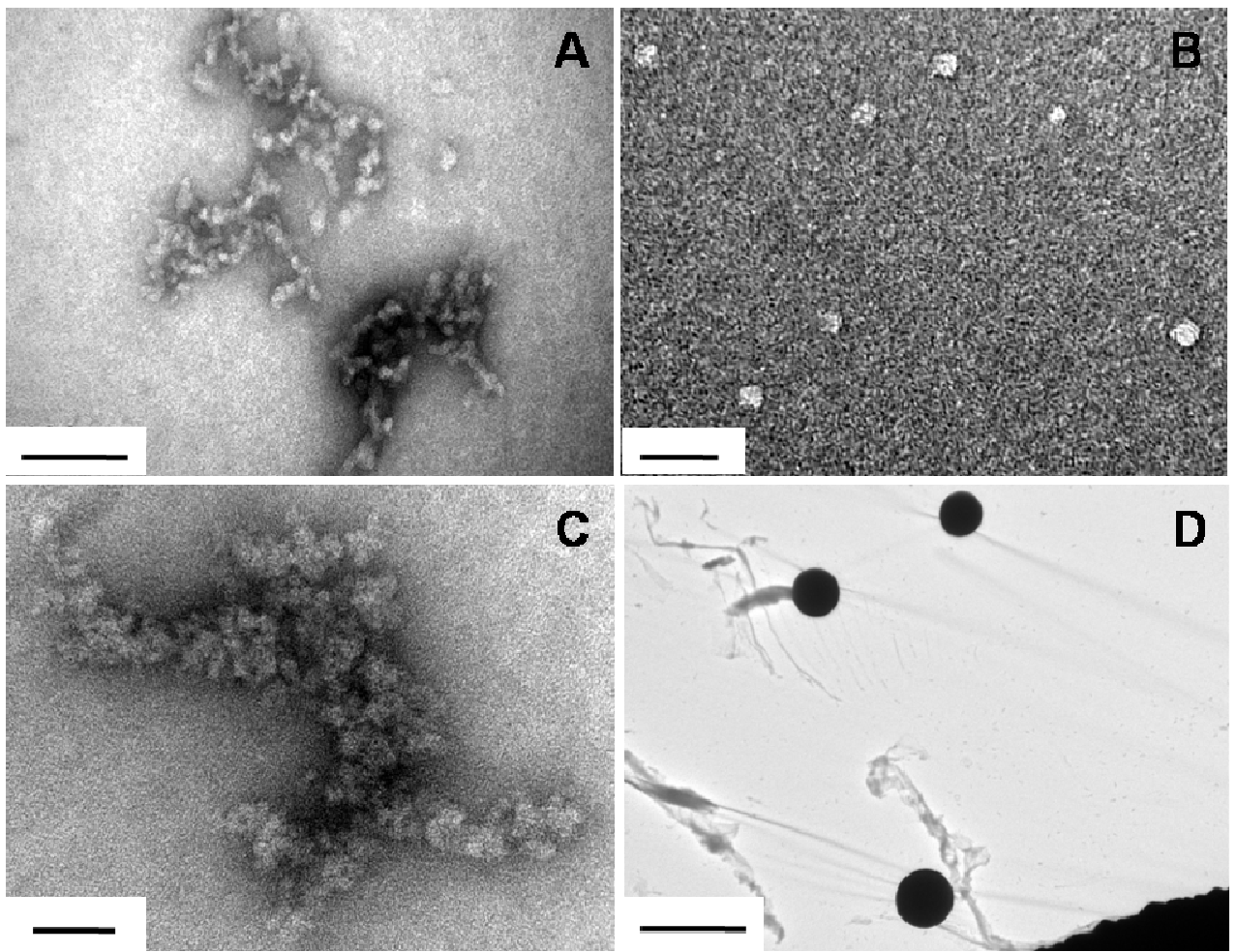

D

Figure 4. Transmission electron micrographs of apo $\alpha$-LA/LYS assemblies obtained at various total protein concentration: (A) $0.02 \mathrm{mM}$, scale bar $=100 \mathrm{~nm}$; (B) $0.04 \mathrm{mM}$ scale bar $=50 \mathrm{~nm} ;(C) 0.1 \mathrm{mM}$ scale bar $=100 \mathrm{~nm}$ and (D) $0.2 \mathrm{mM}$, scale bar $=5 \mu \mathrm{m}$.

\section{Figure 5}




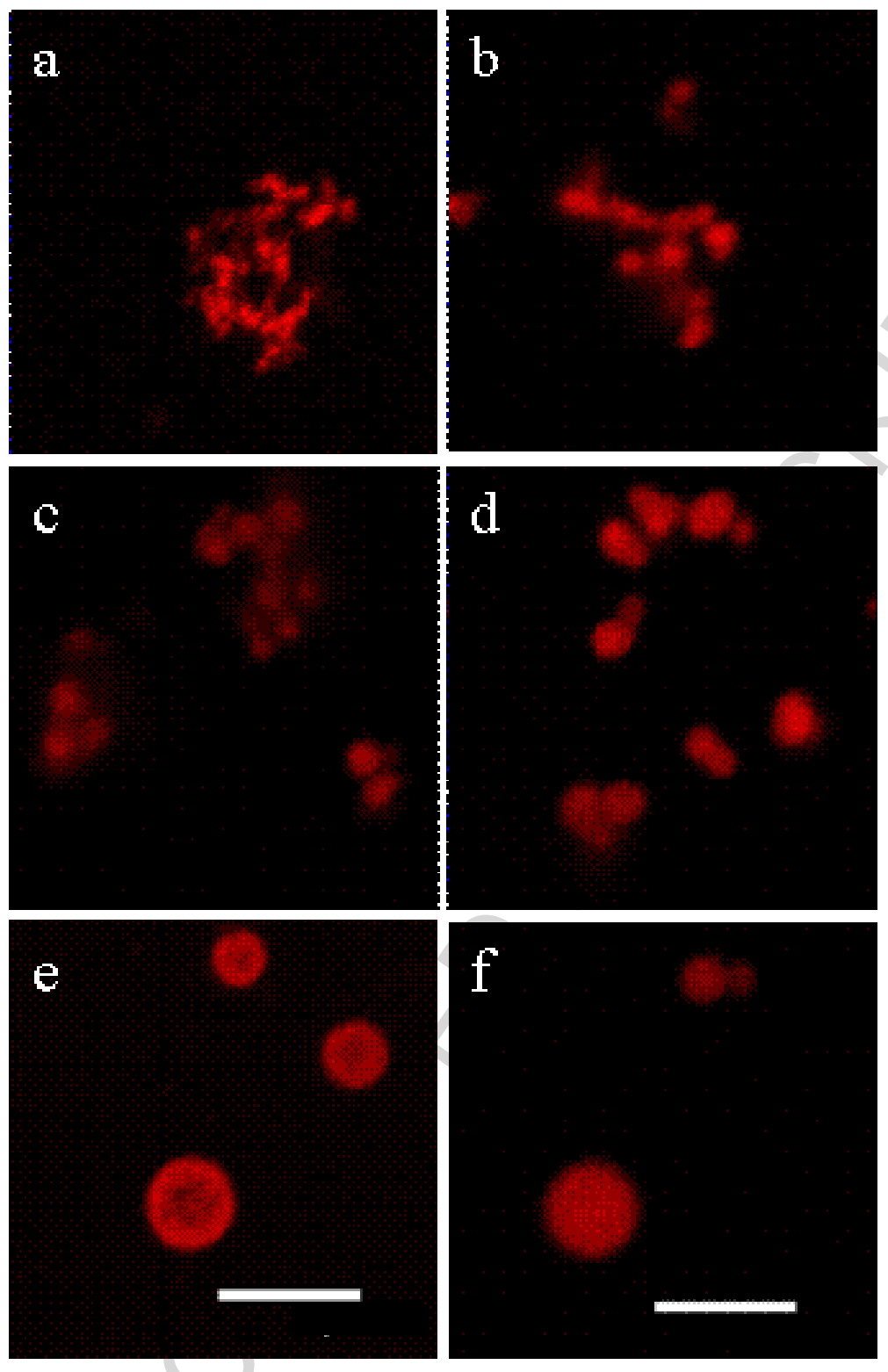

Figure 5. Reorganization of apo $\alpha$-LA/LYS supramolecular structures over time as assessed by confocal scanning laser microscopy. Solution of apo $\alpha$-LA $(0.2 \mathrm{mM})$ was mixed with LYS $(0.2 \mathrm{mM})$ and aliquots were taken at various times. (a), $0.5 \mathrm{~min}$; (b) $1 \mathrm{~min}$; (c) $2 \mathrm{~min}$; (d) 4 $\min$; (e) $6 \mathrm{~min}$; (f) $20 \mathrm{~min}$. Scale bar $=5 \mu \mathrm{m}$.

\section{Figure 6}




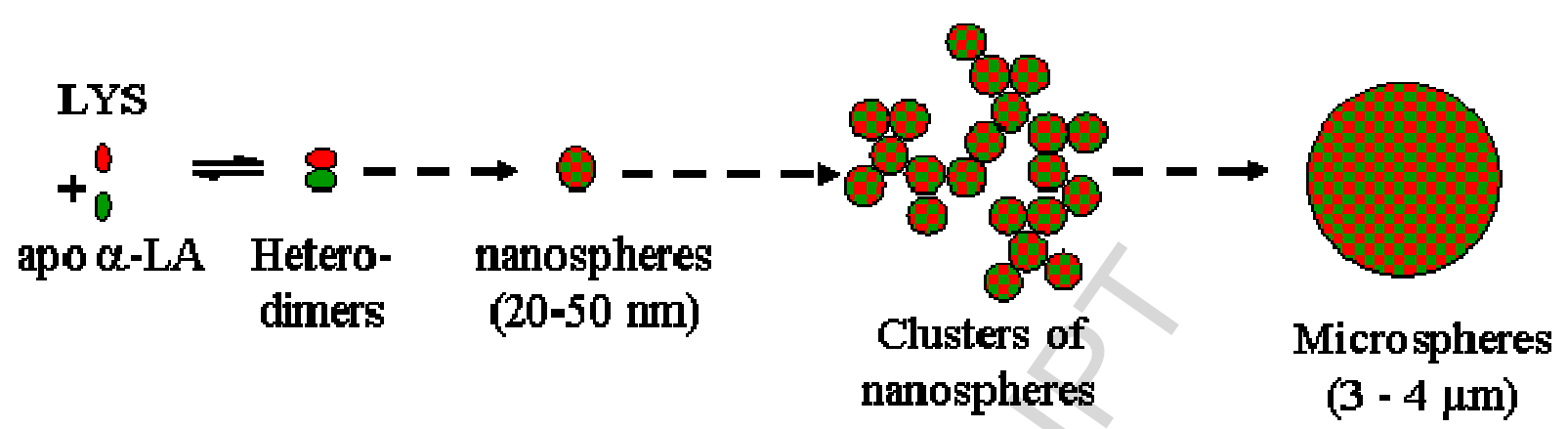

Figure 6. Putative mechanism for apo $\alpha$-LA/LYS assembly into spherical particles at $45^{\circ} \mathrm{C}$. LYS and apo $\alpha$-LA interact to form heterodimers witch further self-assemble into spheres throughout reorganization of clustered small spherical particles. 